\title{
Prevalence of Helicobacter pylori vacA, cagA and iceA genotypes in Nigerian patients with duodenal ulcer disease
}

\author{
STELLA I. SMITH*,+ CHRISTIAN KIRSCH*, KOLA S. OYEDEJI*, ANTHONY O. ARIGBABU§, \\ AKITOYE O. COKER\|, EKKEHARD BAYERDÖFFER* and STEPHAN MIEHLKE* \\ * Medical Department I, Gastroenterology, Hematology, Oncology, Pulmonology and Infectious Diseases, \\ Technical University Hospital, Dresden, Germany, †Genetics Division and \$Microbiology Division, Nigerian \\ Institute of Medical Research, Yaba, Lagos, §Department of Surgery, Obafemi Awolowo University Teaching \\ Hospital Complex, Ile-Ife and \|Department of Medical Microbiology and Parasitology, College of Medicine, \\ University of Lagos, Idi-Araba, Lagos, Nigeria
}

\begin{abstract}
Distinct virulence factors of Helicobacter pylori have been associated with clinical outcome of the infection; however, considerable variations have been reported from different geographic regions. Data on genotypes of African $\boldsymbol{H}$. pylori isolates are sparse. The aim of this study was to determine the prevalence of specific genotypes of $\mathrm{H}$. pylori in Nigerian patients with duodenal ulcer and non-ulcer dyspepsia. $H$. pylori was cultured from endoscopic biopsies obtained from 41 Nigerian patients (19 with duodenal ulcer, 22 with non-ulcer dyspepsia). The vac $A$ alleles, $\operatorname{cag} A$ and ice $A$ genotypes were determined by PCR. The vac $A \mathrm{~s} 1, \mathrm{~m} 1$ and $\mathrm{s} 1, \mathrm{~m} 2$ genotypes were found in $26.3 \%$ and $22.7 \%$, and in $\mathbf{7 3 . 7 \%}$ and $\mathbf{7 2 . 7 \%}$ of $\mathrm{H}$. pylori isolates from patients with duodenal ulcer and non-ulcer dyspepsia, respectively. The ice $A 1$ genotype was present in $94.7 \%$ and $86.4 \%$ of isolates from duodenal ulcer and non-ulcer dyspepsia patients, respectively. $\operatorname{cag} A^{+}$infection was found predominantly $(>90 \%)$ in Nigerian $H$. pylori isolates irrespective of the clinical diagnosis. In conclusion, $v a c A \mathrm{~s} 1, \mathrm{~m} 2$, ice $A 1$ and $\operatorname{cag} A^{+}$are common genotypes of $H$. pylori isolated from Nigerian patients. As in several other developing countries there seems to be no association between these genotypes and duodenal ulcer disease.
\end{abstract}

\section{Introduction}

Helicobacter pylori is a common infection world-wide, the aetiological agent of chronic active gastritis and the major cause of peptic ulcer disease and primary gastric lymphoma of MALT type [1,2]. H. pylori has also been recognised as a risk factor for gastric adenocarcinoma [3]. The reasons for these different outcomes of $H$. pylori infection remain unclear. Several $H$. pylori genes that are related to the risk of disease have been proposed. The cytotoxin-associated gene $(\operatorname{cag} A)$ is a marker for a genomic pathogenicity island of $c .40 \mathrm{~kb}$ and its presence is thought to be associated with a more severe clinical outcome of the infection $[4,5]$. $\operatorname{cag} A$ is thought to be closely related to the vacuolating cytotoxin, encoded by the vacA gene. The vacA gene is

Received 24 Jan. 2002; revised version received 3 April 2002; accepted 12 April 2002.

Corresponding author: Dr S. Miehlke (email: miehlke@, mk1.med.tu-dresden.de). present in virtually all $H$. pylori strains and contains at least two variable regions, the signal and the middle regions [6]. Strains harbouring the vacA s1 genotype show a high cytotoxic activity and have been linked to severe clinical disease such as peptic ulcer disease [7]. Another recently described putative virulence factor is ice $A$ (induced by contact with the epithelium), which exists in at least two allelic forms, ice A1 and ice $A 2$ [8]. ice $A 1$ is upregulated upon contact of $H$. pylori with the gastric epithelium and has been also been suggested as a marker for peptic ulcer disease [9].

Subsequent studies have shown considerable inconsistencies of these associations, depending on the population or geographic origin of the isolates $[10,11]$. There are few data available as regards the pattern of $H$. pylori genotypes in patients from African populations $[12,13]$. Therefore, the aim of this study was to investigate the prevalence of the $v a c A, \operatorname{cag} A$ and ice $A$ genotypes of $H$. pylori isolates from Nigerian patients with duodenal ulcer or non-ulcer dyspepsia. 


\section{Materials and methods}

\section{Patients and H. pylori isolates}

A total of $41 \mathrm{H}$. pylori isolates was obtained from 19 patients with active duodenal ulcer disease, and from 22 patients with dyspeptic symptoms, who had no current evidence and no history of peptic ulcer. All biopsies for primary $H$. pylori culture were obtained from the gastric antrum. The biopsies were smeared immediately on to Columbia agar base medium containing Dent's supplement and laked horse blood 7\%. The plates were incubated at $37^{\circ} \mathrm{C}$ for $3-7$ days under micro-aerobic conditions. H. pylori was identified by typical Gram's stain and colony morphology, and by positive biochemical tests for urease, catalase and oxidase.

\section{H. pylori genotyping}

Bacterial chromosomal DNA was extracted from freshly harvested $H$. pylori cultures with phenol/ chloroform. For PCR analysis of the targeted genes $2 \mu \mathrm{l}$ of DNA were added to $50 \mu \mathrm{l}$ of reaction mixture containing $1 \times$ PCR buffer, $1.5 \mathrm{mM} \mathrm{MgCl}_{2}, 0.2 \mathrm{mM}$ (each) deoxynucleotide (Gibco BRL, Germany) and $0.5 \mu \mathrm{M}$ of respective oligonucleotide primers. AmpliTaq Gold (Perkin Elmer, Germany) 2.5 U was added to each tube and overlaid with mineral oil. PCR was performed with a thermal cycler (GeneAmp 2400; Perkin Elmer). The amplification cycles (cagA, vacA $\mathrm{s} 1 / \mathrm{s} 2$ and ice A) consisted of an initial denaturation of target DNA at $94^{\circ} \mathrm{C}$ for $9 \mathrm{~min}$ and then denaturation at $94^{\circ} \mathrm{C}$ for $1 \mathrm{~min}$, primer annealing at $60^{\circ} \mathrm{C}$ or $56^{\circ} \mathrm{C}$ (vacA $\mathrm{m} 1, \mathrm{~m} 2$ ) for $1 \mathrm{~min}$ and extension at $72^{\circ} \mathrm{C}$ for $1 \mathrm{~min}$ (35 cycles). The final cycle included an extension step for $5 \mathrm{~min}$. The primers used to amplify the targeted genes are summarised in Table $1[6,9,14]$. Negative controls were added to each PCR run including all reagents except template DNA. H. pylori ATCC 49503 was used as the positive control. PCR products were visualised by agarose $1.5 \%$ gel electrophoresis.

\section{Results}

Fig. 1 shows the results of electrophoresis of PCR products. The predicted 259-bp PCR product for vacA s1

Table 1. PCR primers for amplification of $\operatorname{cag} A, v a c A$ and ice $A$ sequences

\begin{tabular}{|c|c|c|c|}
\hline Gene & Primer sequence $\left(5^{\prime}-3^{\prime}\right)$ & PCR product $(\mathrm{bp})$ & Reference no. \\
\hline $\operatorname{cag} A$ & $\begin{array}{l}\text { TTGACCAACAACCACAAACCGAAG } \\
\text { CTTCCCTTAATTGCGAGATTCC }\end{array}$ & 183 & 14 \\
\hline$v a c A \mathrm{~s} 1 / \mathrm{s} 2$ & $\begin{array}{l}\text { GGTCAAAATGCGGTCATGG } \\
\text { CTGCTTGAATGCGCCAAAC }\end{array}$ & $259 / 286$ & 6 \\
\hline$v a c A \mathrm{~m} 1$ & $\begin{array}{l}\text { GGTCAAAATGCGGTCATGG } \\
\text { CCATTGGTACCTGTAGAAAC }\end{array}$ & 290 & 6 \\
\hline$v a c A \mathrm{~m} 2$ & $\begin{array}{l}\text { GGAGCCCCAGGAAACATTG } \\
\text { CATAACTAGCGCCTTGCAC }\end{array}$ & 352 & 6 \\
\hline iceA 1 & $\begin{array}{l}\text { GTTGGGTAAGCGTTACAGAATTT } \\
\text { CATTGTATATCCTATCATTAC }\end{array}$ & 567 & 9 \\
\hline iceA2 & $\begin{array}{l}\text { GTTGGGTATATCACAATTTAT } \\
\text { TTRCCCTATTTTCTAGTAGGT }\end{array}$ & 229 or 334 & 9 \\
\hline
\end{tabular}

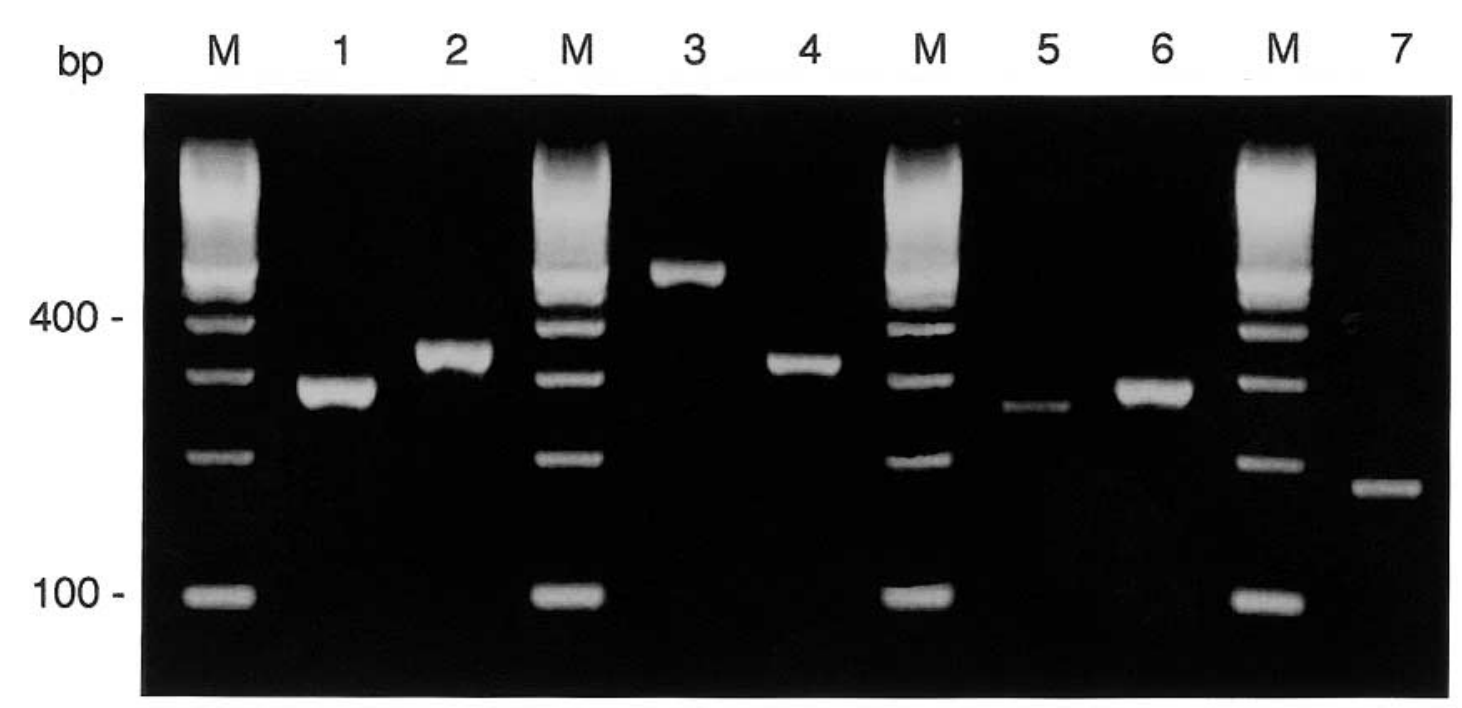

Fig. 1. Agarose $1.5 \%$ gel electrophoresis of PCR products for $H$. pylori genotyping. Lanes: M, 100-bp ladder; 1 and 2, vacA m1 and $\mathrm{m} 2 ; \mathbf{3}$ and $\mathbf{4}, i c e A 1$ and ice $A 2 ; \mathbf{5}$ and $\mathbf{6}, v a c A$ s 1 and $\mathrm{s} 2 ; \mathbf{7}, \operatorname{cag} A$. 
was identified in $40 \mathrm{H}$. pylori strains $(98 \%)$. As shown in Table 2, the majority of isolates harboured the vacA $\mathrm{s} 1, \mathrm{~m} 2$ genotype, followed by the $\mathrm{s} 1, \mathrm{~m} 1$ genotype. A $v a c A \mathrm{~s} 2, \mathrm{~m} 1$ genotype has not been found. There were no significant differences between the two patient groups.

The 183-bp PCR product indicating the presence of the $\operatorname{cag} A$ gene was obtained with 38 isolates (93\%). cag $A^{+}$ infection was present in $95 \%$ of duodenal ulcer patients and in $91 \%$ of patients with non-ulcer dyspepsia $(\mathrm{p}>0.05)$.

All H. pylori isolates possessed the iceA gene. In all, 37 isolates $(90.2 \%)$ were positive for ice $A 1$, of which $18(94.7 \%)$ were from duodenal ulcer patients and 19 (86.4\%) from non-ulcer dyspepsia patients (Table 2). A PCR product for both ice $A 1$ and ice $A 2$ was obtained from only one isolate from a non-ulcer dyspepsia patient.

The combined vacA $\mathrm{s} 1 / \mathrm{cag} A^{+} /$ice $A 1$ genotype was present in $82.5 \%$ of all $H$. pylori isolates (Table 3 ).

\section{Discussion}

The study demonstrated a high prevalence of $H$. pylori infection of the $v a c A \mathrm{~s} 1, \operatorname{cag} A^{+} /$ice $A 1^{+}$genotype in patients from Nigeria with duodenal ulcer disease or non-ulcer dyspepsia. Therefore, this study is consistent with previous reports from the USA, Europe and Asia

Table 2. Genotype status of $41 \mathrm{H}$. pylori isolates from Nigerian patients with duodenal ulcer disease or nonulcer dyspepsia

\begin{tabular}{lccc}
\hline \multicolumn{4}{c}{$\begin{array}{c}\text { Number }(\%) \text { of isolates } \\
\text { from patients with }\end{array}$} \\
\cline { 2 - 3 } & $\begin{array}{c}\text { duodenal ulcer } \\
\text { disease }(\mathrm{n}=19)\end{array}$ & $\begin{array}{c}\text { non-ulcer dyspepsia } \\
(\mathrm{n}=22)\end{array}$ & \\
Genotype & $5(26.3)$ & $5(22.7)$ & $10(24.4)$ \\
\hline vacA $\mathrm{s} 1 \mathrm{~m} 1$ & $14(73.7)$ & $16(72.7)$ & $30(73.2)$ \\
$\mathrm{s} 1 \mathrm{~m} 2$ & $1(4.5)$ & $1(2.5)$ & $2(4.9)$ \\
$\mathrm{s} 2 \mathrm{~m} 2$ & $18(94.7)$ & $20(90.9)$ & $38(92.7)$ \\
cag $A^{+}$ & $18(94.7)$ & $19(86.4)$ & $37(90.2)$ \\
ice $A 1$ & $1(5.3)$ & $2(9.1)$ & $3(7.3)$ \\
ice $A 2$ & 0 & $1(4.5)$ & $1(2.5)$ \\
ice $A 1^{+}$, ice $A 2^{+}$ & 0 & & \\
\hline
\end{tabular}

Table 3. Combined $v a c A, \operatorname{cag} A$ and iceA genotypes

\begin{tabular}{lccc}
\hline & \multicolumn{2}{c}{$\begin{array}{c}\text { Number }(\%) \text { of isolates } \\
\text { from patients with }\end{array}$} & \\
\cline { 2 - 4 } & $\begin{array}{c}\text { Duodenal } \\
\text { ulcer disease } \\
(\mathrm{n}=19)\end{array}$ & $\begin{array}{c}\text { Non-ulcer } \\
\text { dyspepsia } \\
(\mathrm{n}=21)\end{array}$ & \\
Genotype & $17(89.5)$ & $16(76.2)$ & $33(82.5)$ \\
\hline vacA $\mathrm{s} 1 / \mathrm{cag} A^{+} /$ice $A 1$ & $1(5.3)$ & $2(9.5)$ & $3(7.5)$ \\
vacA $\mathrm{s} 1 / \mathrm{cag} A^{+} /$iceA2 & $1(5.3)$ & $2(9.5)$ & $3(7.5)$ \\
vacA $\mathrm{s} 1 / \mathrm{cag}^{-} /$ice $A 1$ & 0 & $1(4.8)$ & $1(2.5)$ \\
vacA $\mathrm{s} 2 / \mathrm{cagA}^{+} /$ice 1 & & & \\
\hline
\end{tabular}

suggesting that $\operatorname{cag} A$ status and the $v a c A$ genotype of $H$. pylori may not predict the clinical outcome of infection [10,15]. In contrast, another study from South Africa has shown that the vacA s1 allele accounted for $100 \%$ of ulcer strains and $67 \%$ of gastritis strains [12]. In that study, the vacA s2 type was found exclusively in gastritis patients, whereas in the present study the s2 allele was detected in only one patient with non-ulcer dyspepsia. In the present study, the vacA middle region types were not independently associated with the occurrence of peptic ulceration, which is in agreement with the study by Kidd et al. [12]. Another report by Letley et al. [13] supports these results, in that the vacA middle region polymorphism is not related to peptic ulceration. Kidd et al. also described the first case of a vacA s2,m1 H. pylori isolate from a duodenal ulcer patient [12]. The present study did not find such a genotype among a central African population. The prevalence of $\operatorname{cag} A^{+}$strains in Nigerian peptic ulcer patients and those with non-ulcer dyspepsia was similar to that shown in the study from South Africa. To our knowledge, this is the first study on alleles of the iceA gene in $H$. pylori isolates from Africa. In contrast to a previous report by van Doorn et al. [9], no association was found between the ice $A 1$ allele and peptic ulcer disease. In another study by Yamaoka et al. [10], the iceA1 allele was predominant in Japanese and Korean populations, whereas iceA2 was prevalent in the USA and Colombia. An association between ice $A 1$ and severity of clinical disease could not be shown in either population. This is also consistent with other studies from Asia suggesting that $\operatorname{cag} A$, vacA and the ice $A$ genotype were not associated with peptic ulcer disease [16].

In conclusion, this study demonstrated that vacA $\mathrm{s} 1$, ice $A 1$ and $\operatorname{cag} A^{+}$are common genotypes of $H$. pylori in Nigeria. As in other developing countries, there seems to be no association between these genotypes and duodenal ulcer disease in this particular population.

S.I.S. is supported by the Alexander von Humboldt Stiftung, Bonn, Germany (IV NRI 1067290 STP). The study was presented at the XIVth International Workshop on Gastroduodenal Pathology and Helicobacter pylori, Strasbourg, France, September 2001.

\section{References}

1. Graham DY. Helicobacter pylori infection in the pathogenesis of duodenal ulcer and gastric cancer: a model. Gastroenterology 1997; 113: 1983-1991.

2. Bayerdörffer E, Miehlke S, Neubauer A, Stolte M. Gastric MALT-lymphoma and Helicobacter pylori infection. Aliment Pharmacol Ther 1997; 11 (Suppl 1): 89-94.

3. International Agency of Research on Cancer, Working Group on the Evaluation of Carcinogenic Risks to Humans. Schistosomes, liver flukes and Helicobacter pylori. IARC Monogr Eval Carcinog Risks Hum 1994; 61: 1-241.

4. Censini S, Lange $\mathrm{C}$, Xiang $\mathrm{Z}$ et al. cag, a pathogenicity island of Helicobacter pylori, encodes type I-specific and diseaseassociated virulence factors. Proc Natl Acad Sci USA 1996; 93: $14648-14653$

5. Akopyants NS, Clifton SW, Kersulyte D et al. Analyses of the 
cag pathogenicity island of Helicobacter pylori. Mol Microbiol 1998; 28: 37-54

6. Atherton JC, Cao P, Peek RM, Tummuru MKR, Blaser MJ, Cover TL. Mosaicism in vacuolating cytotoxin alleles of Helicobacter pylori. Association of specific vacA types with cytotoxin production and peptic ulceration. J Biol Chem 1995; 270: $17771-17777$.

7. Atherton JC, Peek RM, Tham KT, Cover TL, Blaser MJ Clinical and pathological importance of heterogeneity in vacA, the vacuolating cytotoxin gene of Helicobacter pylori. Gastroenterology 1997; 112: 92-99.

8. Peek RM, Thompson SA, Donahue JP et al. Adherence to gastric epithelial cells induces expression of a Helicobacter pylori gene, iceA, that is associated with clinical outcome. Proc Assoc Am Physicians 1998; 110: 531-544.

9. van Doorn L-J, Figueiredo C, Sanna R et al. Clinical relevance of the cagA, vacA, and iceA status of Helicobacter pylori. Gastroenterology 1998; 115: 58-66.

10. Yamaoka Y, Kodama T, Gutierrez O, Kim JG, Kashima K, Graham DY. Relationship between Helicobacter pylori iceA, cagA, and vacA status and clinical outcome: studies in four different countries. J Clin Microbiol 1999; 37: 2274-2279.

11. Van Doorn L-J, Figueiredo C, Mégraud F et al. Geographic distribution of vacA allelic types of Helicobacter pylori. Gastroenterology 1999; 116: 823-830.

12. Kidd M, Lastovica AJ, Atherton JC, Louw JA. Heterogeneity in the Helicobacter pylori vacA and cagA genes: association with gastroduodenal disease in South Africa? Gut 1999; 45: 499-502.

13. Letley DP, Lastovica A, Louw JA, Hawkey CJ, Atherton JC. Allelic diversity of the Helicobacter pylori vacuolating cytotoxin gene in South Africa: rarity of the vacA sla genotype and natural occurrence of an $\mathrm{s} 2 / \mathrm{m} 1$ allele. $J$ Clin Microbiol 1999; 37: 1203-1205.

14. Covacci A, Rappuoli R. PCR amplification of gene sequences from Helicobacter pylori strains. In: Lee A, Mégraud F (eds) Helicobacter pylori: techniques for clinical diagnosis and basic research. London, WB Saunders. 1996: 94-111.

15. Miehlke S, Kibler K, Kim JG et al. Allelic variation in the cagA gene of Helicobacter pylori obtained from Korea compared to the United States. Am J Gastroenterol 1996; 91: $1322-1325$.

16. Zheng PY, Hua J, Yeoh KG, Ho B. Association of peptic ulcer with increased expression of Lewis antigens but not cagA, ice $\mathrm{A}$, and vacA in Helicobacter pylori isolates in an Asian population. Gut 2000; 47: 18-22. 